\section{Humicolin, a New Antibiotic}

Ir has been shown by P. J. Curtis, H. G. Hemming and E. G. Jefferys that Aspergillus humicola, a fungus obtained from soil in deep caves, produces an antifungal substance to which the name humicolin has been given (Trans. Brit. Mycol. Soc., 35, Part 4, 263 ; December 1952). The substance is obtained by extraction of culture filtrates with charcoal, from which it is eluted with carbon tetrachloride. It is a weakly acidic yellow oil, soluble in petrol ether, contains no nitrogen, sulphur or halogen, but probably has a phenolic or enolic group; it crystallizes from methanol at $-80^{\circ}$ C., distils at $210-215^{\circ}$ C. at $10^{-2} \mathrm{~mm}$. of mercury, is moderately stable in aqueous solution at $p \mathrm{H} 3 \cdot 5-4 \cdot 5$, but is inactivated at higher $p H$ values. Humicolin inhibits the spore germination of several common fungi--.at concentrations ranging from $0.4 \mu \mathrm{gm} . / \mathrm{ml}$. for Fusarium coruleum to 12.5 $\mathrm{gm} . / \mathrm{ml}$. for Trichoderma viride, though spores of Absidia glauca are not prevented from germinating by $50 \mu \mathrm{gm} . / \mathrm{ml}$.

\section{Radioactive Cortisone and Hydrocortisone}

A LIMITED supply of radioactive cortisone and hydrocortisone is now available without charge to qualified investigators through funds supplied by the National Institute of Arthritis and Metabolic Diseases, Public Health Service. Both are labelled at position 4 with carbon-14. The cortisone has a specific activity of $0.49 \mathrm{mC} . / \mathrm{m}$. mole, and the hydrocortisone a specific activity of $1.47 \mathrm{mC} . \mathrm{m}$. mole. Requests, in the form of a letter concisely describing the proposed research, should be sent to the Division of Research Grants, National Institutes of Health, Bethesda 14, Maryland, U.S.A. Transfer and use of these materials are subject to current regulations of the U.S. Atomic Energy Commission. Synthesis of these ring-labelled compounds was an international co-operative effort : the United States Atomic Energy Commission supplied the radiocarbon; Charles E. Frosst and Co., of Montreal, synthesized the radiocortisone, with help from the Upjohn Company; the Worcester Foundation, utilizing radioactive progesterone prepared by Frosst, prepared the hydrocortisone by biosynthesis.

\section{University of Leeds}

Dr. R. D. Preston, reader in plant biophysics in the University, has been appointed professor of plant biophysies in the Department of Botany as from October $l$.

Dr. W. A. Sledge, lecturer in botany, has been granted leave of absence for the second term of session 1953-54, to enable him to continue researches on the fern flora of Ceylon.

The following gifts have been received: for the Clothworkers' Departments, $£ 1,550$ for 1952-53 from Courtaulds, Ltd., to be used as follows- $£ 700$ for scholarships, $£ 600$ for research in the Department of Textile Industries, £250 for research in the Department of Colour Chemistry and Dyeing; for the Department of Inorganic and Physical Chemistry, $£ 1,500$ from the Department of Scientific and Industrial Research for crystallographic computations on the electronic computer at the University of Manchester.

\section{Swiss Society for Natural Sciences}

The Swiss Society for Natural Sciences will hold its 133rd annual meeting at Lugano during September 5-7, under the presidency of State Councillor Dr. B. Galli. Medical biology will again be to the fore, with a general session on radioactive isotopes, and so will medical psychology and psychiatry with a historical session. Prof. A. Lombard, of Brussels, reporting on his 1952 Everest Mission, and Prof. G. Polvani, of Milan, speaking about Volta's notes on a journey through the St. Gotthard, will interest a general audience. The supporting section programme is fullest in chemistry, with speakers from Heidelberg, Marburg, Milan, Boston and Philadelphia. A notable communication announced in the combined programme for geophysics, meteorology and astronomy is one on echosondage of the atmosphere by Prof. $J$. Lugeon, of Zurich. Botanists will discuss polyploids with the zoologists and geneticists. The meeting will be followed by a visit to the electric generating station in the Valle Maggia, a botanical excursion to the Isola di Brissago, and extensive geological tours.

\section{Announcements}

WE regret to announce the death on July 26 of Dr. M. H. Gordon, C.M.G., C.B.E., F.R.S., consulting bacteriologist at St. Bartholomew's Hospital, London, aged eighty-one years.

ThE Society of Dyers and Colourists has elected Mr. J. G. Hopkinson to be honorary secretary in succession to Mr. J. Barritt, who has resigned owing to the pressure of other commitments. Mr. Barritt will, however, continue as chairman of the editorial panel and serve the Society in other branches of its work dealing with publications. Mr. Hopkinson, who is a graduate in chemistry of the University of Oxford and has studied dyeing and textiles at the University of Leeds and Bradford Technical College, is a director of Hopkinson and Shore, Ltd., dyers and finishers of Brighouse, Yorks.

A GLAXo Laboratories Researah Fellowship has been granted through the Friends of the Hebrew University to Miss Alisa Tietz, a graduate of the Hebrew University of Jerusalem, who is at present doing research in the Biochemistry Division of the Medical Research Council in London under Dr. A. Neuberger.

ACCORDING to a written statement made in the House of Commons on July 15 by the Secretary of State for the Colonies on the subject of technical officers in agricultural departments of Colonial Territories, out of a full establishment of $\mathbf{1 , 2 7 0}$ officers serving an area of more than 25,000 square miles the number of vacancies known to the Secretary of State is 122. Seventy-seven candidates have been selected but are still in training, leaving fortyfive vacancies still unfilled.

THE triennial award of the Coopers Hill War Memorial Prize and Medal has been made by the Institution of Electrical Engineers to Mr. G. Lyon, for his paper on "Some Experience with a British A.C. Network Analyser". The Coopers Hill War Memorial Prize, which was founded by the members of the Royal Indian Engineering College, Coopers Hill, in commemoration of members of the College who fell during the First World War, is awarded annually by the Institution of Civil Engineers, and triennially in turn by the Institution of Electrical Engineers, the School of Military Engineering, Chatham, and the School of Forestry, Oxford. It consists of a bronze medol, a certificate and about $£ 20$ in money, and is given for the best paper on a professional subject published by the Institution during the period concerned, the award being restricted to corporate members less than thirty-five years of age. 